\title{
Phase Relation in the System $\mathrm{Ca}_{3}\left(\mathrm{PO}_{4}\right)_{2}-\mathrm{MgSiO}_{3}$
}

\author{
Toshiyuki SATA ${ }^{\dagger}$ \\ Department of Industrial Chemistry, Kumamoto Institute of Technology, 4-22-1, Ikeda, Kumamoto-shi 860 \\ $\mathrm{Ca}_{3}\left(\mathrm{PO}_{4}\right)_{2}-\mathrm{MgSiO}_{3}$ 系の相関係 \\ 佐多敏之† \\ 熊本工業大学工業化学科, 860 熊本市池田 4-22-1
}

\begin{abstract}
Phase relations in the system tricalcium phosphate $\left(3 \mathrm{CaO} \cdot \mathrm{P}_{2} \mathrm{O}_{5}=\mathrm{C}_{3} \mathrm{P}\right)$-enstatite $\left(\mathrm{MgO} \cdot \mathrm{SiO}_{2}=\mathrm{MS}\right)$ have been investigated in the temperature range 1100 to $1600^{\circ} \mathrm{C}$ by means of the quenching method. $\mathrm{C}_{3} \mathrm{P}$ takes $\beta$-type (whitrockite) in a wide region by dissolution of $\mathrm{MgO}$, and diopside (d) appeared in the composition range more than 40 mass $\% \mathrm{C}_{3} \mathrm{P}$ by a reach in between $\mathrm{MgSiO}_{3}$ and liberated $\mathrm{CaO}$. The enstatite transfers to iron-free pigeonite (pi) by taking $\mathrm{CaO}$ in an MS-rich region, where pi coexists with protoenstatite, $\mathrm{MgSiO}_{3}$ (pr). Primary crystals which appeared in a wide region are $\beta$ - $\mathrm{C}_{3} \mathrm{P}$ and pi, and primary diopside appears in a narrow region at a minimum temperature $\left(1265-1305^{\circ} \mathrm{C}\right)$. In the subsolidus region below $1245^{\circ} \mathrm{C}, \beta-\mathrm{C}_{3} \mathrm{P}$ coexists with $\mathrm{d}$, pi or pi-pr mixture. The system is not binary and it should be discussed from the ternary system $\mathrm{C}_{3} \mathrm{P}-\mathrm{M}-\mathrm{S}$ and the quaternary system $\mathrm{C}_{3} \mathrm{P}-\mathrm{CMS}_{2}-\mathrm{MS}-\mathrm{S}$.

[Received November 17, 1995; Accepted February 9, 1996]
\end{abstract}

Key-words : Phase diagram, The system $\mathrm{Ca}_{3}\left(\mathrm{PO}_{4}\right)_{2}-\mathrm{MgSiO}_{3}$, Tricalcium phosphate, Magnesium silicate, Diopside, Pigeonite

\section{Introduction}

In the system $\mathrm{CaO}-\mathrm{P}_{2} \mathrm{O}_{5},{ }^{1)-5)} 6$ kinds of phosphates with $\mathrm{CaO} / \mathrm{P}_{2} \mathrm{O}_{5}$ molar ratios of $4,3,2,1$, $2 / 3$ and $1 / 2$ have been reported (Figs. 245, 246, 247, 248 and 250 in "Phase Diagrams for Ceramists"6)). Among these Ca-phosphates, $3: 1$ compound $\mathrm{Ca}_{3}\left(\mathrm{PO}_{4}\right)_{2}=3 \mathrm{CaO} \cdot \mathrm{P}_{2} \mathrm{O}_{5}=\mathrm{C}_{3} \mathrm{P}$ is a major component of phosphate rock (apatite $=\mathrm{Ca}_{5}\left(\mathrm{PO}_{4}\right)_{3} \mathrm{~F}$ ), which has been used to manufacture phosphate fertilizers (superphosphate, water soluble 1: 1 compopund produced by reaction with $\mathrm{H}_{2} \mathrm{SO}_{4}$ ). Another phosphate fertilizer is calcium magnesium phosphate which is fabricated by fusion and quenching processes of the phosphate rock with serpentine rock $\left(3 \mathrm{MgO} \cdot 2 \mathrm{SiO}_{2} \cdot 2 \mathrm{H}_{2} \mathrm{O}\right)$. This author investigated on the system $3 \mathrm{CaO} \cdot \mathrm{P}_{2} \mathrm{O}_{5}-\mathrm{MgO} \cdot \mathrm{SiO}_{2}\left(=\mathrm{C}_{3} \mathrm{P}-\right.$ $\mathrm{MS}$ ) in order to find the minimum fusion temperature region for the above fertilizer, and the results were already published in 1958.7) During about 30 years after this publication, phase diagrams in the system diopside-enstatite had been improved. ${ }^{8)-12)}$ Referring to these results, phases present in the system $\mathrm{C}_{3} \mathrm{P}-\mathrm{MS}$ were re-examined in this study. Compositions relating to this region are important for compositions of the above-mentioned fused phosphate fertilizer ${ }^{13)-19)}$ and $\mathrm{P}_{2} \mathrm{O}_{5}$-containing metallurgical slags, and for understanding corrosion mechanism of refractories against $\mathrm{P}_{2} \mathrm{O}_{5}$-containing melts of the above fertilizer and slags. It may be also important for the recently advanced glass ceramics and bioceramics with related compositions. The $\mathrm{C}_{3} \mathrm{P}-\mathrm{MS}$ sys-

\footnotetext{
${ }^{\dagger}$ Current address: 1-28-16, D7-504, Unomori, Sagamiharashi 228

現在連絡先：228 相模原市鵜野森 1-28-16 D7-504
}

tem is one of the most important joins in the 4-component tetrahedron $\mathrm{C}_{3} \mathrm{P}-\mathrm{CMS}_{2}-\mathrm{MS}-\mathrm{S}$ which will be reported later. Any report on this 2-component system has not appeared yet on literature, except for the author's.

\section{Experimental}

A starting materials, tricalcium phosphate $\mathrm{C}_{3} \mathrm{P}$, was synthesized by a reaction of $\mathrm{CaCO}_{3}$ with phosphoric acid at $1200^{\circ} \mathrm{C}$, as described in the previous paper. ${ }^{7)}$ Another $\mathrm{C}_{3} \mathrm{P}$ specimen was synthesized from $\mathrm{CaCO}_{3}$ and $\left(\mathrm{NH}_{4}\right)_{2} \mathrm{HPO}_{4}$ too. For determination of transition temperature of $\mathrm{C}_{3} \mathrm{P}, 3$ levels of calcination temperatures were used, as described later (Section 3.1). Enstatite (MS) was also synthesized by firings of $\mathrm{MgCO}_{3}$ and $\mathrm{SiO}_{2}$ at $1200^{\circ} \mathrm{C}$. After weighing above materials for the nominal compositions, these were thoroughly mixed in an agate mortar using alcohol or acetone. The powdered mixture was pressed to pellets and fired 1 or 2 times at 1350$1400^{\circ} \mathrm{C}$ for $3-5 \mathrm{~h}$ on a platinum plate accompanied by intermediate grindings. Chemical compositions of these fired starting materials were confirmed by chemical analyses.

The powders of the fired specimen was enclosed in the Pt-envelope and then suspended with $\mathrm{Pt}$ wire $(0.5 \mathrm{~mm})$ at a homogeneous temperature region in a mullite tube ( $40 \mathrm{~mm}$ in outer diameter) of a furnace with an SiC spiral heater and was held at a constant temperature controlled within $\pm 1^{\circ} \mathrm{C}$ by a thyrister unit. A thermocouple of $\mathrm{Pt}-\mathrm{Pt} 13 \% \mathrm{Rh}$ alloy was positioned near by the specimen. In the quenching of the specimen into water, the suspending Pt wire was dropped with the sample envelope. The quenched 
specimen was examined mainly by X-ray diffraction analysis (XRD) and $2 \theta$ angles were calibrated using pure silicon powders. Optical microscopy was also applied to confirm a presence of liquid.

The thermocouple used was calibrated by observation of melting points of gold and paradium wires and by quenching method using diopside and wallastonite powders. Generally, 4 or $5^{\circ} \mathrm{C}$ should be added to the read values. $\mathrm{MoSi}_{2}$ furnace and $\mathrm{Pt} 6 \mathrm{Rh}-$ Pt30Rh or Pt20Rh-Pt40Rh thermocouple were used for measurement at temperatures more than $1450^{\circ} \mathrm{C}$.

\section{Results and discussion}

\subsection{Transition temperature of $\mathrm{C}_{3} \mathrm{P}$}

Three kinds of $\mathrm{C}_{3} \mathrm{P}$ specimens synthesized at 900 , 1000 or $1300^{\circ} \mathrm{C}$ for $3 \mathrm{~h}$ were used, as described in the experimental method. These specimens were quenched from $1005-1405^{\circ} \mathrm{C}$ after $1-15$ h holdings. Thus, the transition temperature was compared with the preceding results in the literatures. To know rough contents of $\alpha$-type and $\beta$-type, peak intensities at $24.1^{\circ}$ (261) of $2 \theta$ for $\alpha$-type and $27.7^{\circ}(214)$ for $\beta$ type were used and the transition temperature was determined as a temperature at which $\alpha$-type began to appear from $\beta$-type. The $\mathrm{X}$-ray patterns were referred to 29-359 for $\alpha-\mathrm{C}_{3} \mathrm{P}$ and 9-169 for $\beta-\mathrm{C}_{3} \mathrm{P}$ described in JCPDS data. ${ }^{20)}$

The results of the quenching are listed in Table 1. The quenched temperature in the table shows the maximum temperature in waving temperature controlling of \pm 5 or $\pm 1^{\circ} \mathrm{C}$. Contents of $\beta-\mathrm{C}_{3} \mathrm{P}$ in $\alpha-\beta$ mixtures are plotted against temperatures as shown in Fig. 1. From the figure, the transition temperature between $\alpha$ and $\beta$ is estimated to be between 1100 and $1120^{\circ} \mathrm{C}$. Coexistence of both type $\mathrm{C}_{3} \mathrm{P}$ is observed up to $1260^{\circ} \mathrm{C}$ and it was noted that $\alpha$-type heated at $1300^{\circ} \mathrm{C}$ was difficult to transform to $\beta$-type even in holding at $1100^{\circ} \mathrm{C}$. The transition temperatures of $\beta$ $\alpha$ and of $\alpha-\alpha^{\prime}$ had been reported using the high temperature XRD method as follows:

$$
\begin{array}{cccl}
\beta-\alpha & \alpha-\alpha^{\prime} & \mathrm{mp} & \\
1125^{\circ} \mathrm{C} & 1430^{\circ} \mathrm{C} & 1756^{\circ} \mathrm{C} & \text { by Nurse et al. }{ }^{21)} \\
1120^{\circ} \mathrm{C} & 1470^{\circ} \mathrm{C} & 1800^{\circ} \mathrm{C} & \text { by Fix et al. }{ }^{22)}
\end{array}
$$

Author's values for the $\beta$ to $\alpha$ transition are consistent with these above values. The $\alpha$ to $\alpha^{\prime}$ transition was difficult to observe by XRD at room-temperature and microscopy in the quenching experiments.

\subsection{The system diopside-enstatite}

Many studies ${ }^{8)-12)}$ on the solid solutions between diopside $\left(\mathrm{CMS}_{2}\right)$ and enstatite (MS) had been carried out since a publication by Bowen ${ }^{23}$ ) relating to cooled products of magma, but there are many facts remained obscured even in present. ${ }^{24)}$ In particular, the field for the iron-free pigeonite solid solution was reported in 1972 to $1975^{9)-12)}$ on the phase diagram of the system diopside-enstatite. Natural pigeonite was iron-contained metasilicate $\left(\mathrm{Ca}_{0.04} \mathrm{Mg}_{0.45} \mathrm{Fe}_{0.48}\right.$ $\left.\left.\left.\mathrm{SiO}_{3}\right), 25\right), 26\right)$ and iron-free pigeonite with a composition $\mathrm{Ca}_{0.09} \mathrm{Mg}_{0.91} \mathrm{SiO}_{3}{ }^{9), 10)}$ newly formed at $\mathrm{Mg}$-rich
Table 1. Quenching Experiments for $\mathrm{Ca}_{3}\left(\mathrm{PO}_{4}\right)_{2}\left(=\mathrm{C}_{3} \mathrm{P}\right)$. Specimen 434 was Synthesized from $\mathrm{CaCO}_{3}$ and $\mathrm{H}_{3} \mathrm{PO}_{4}$ and 404 from $\mathrm{CaCO}_{3}$ and $\left(\mathrm{NH}_{4}\right)_{2} \mathrm{HPO}_{4}$. Temperature Controls were Generally in $\pm 5^{\circ} \mathrm{C}$ and ${ }^{*}$ Indicates Those in $\pm 1^{\circ} \mathrm{C}$

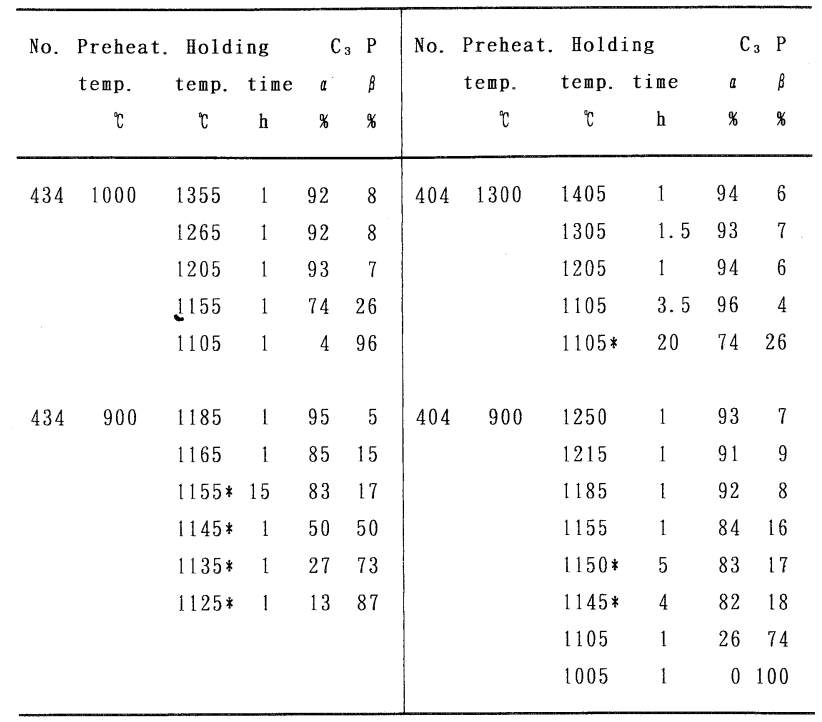

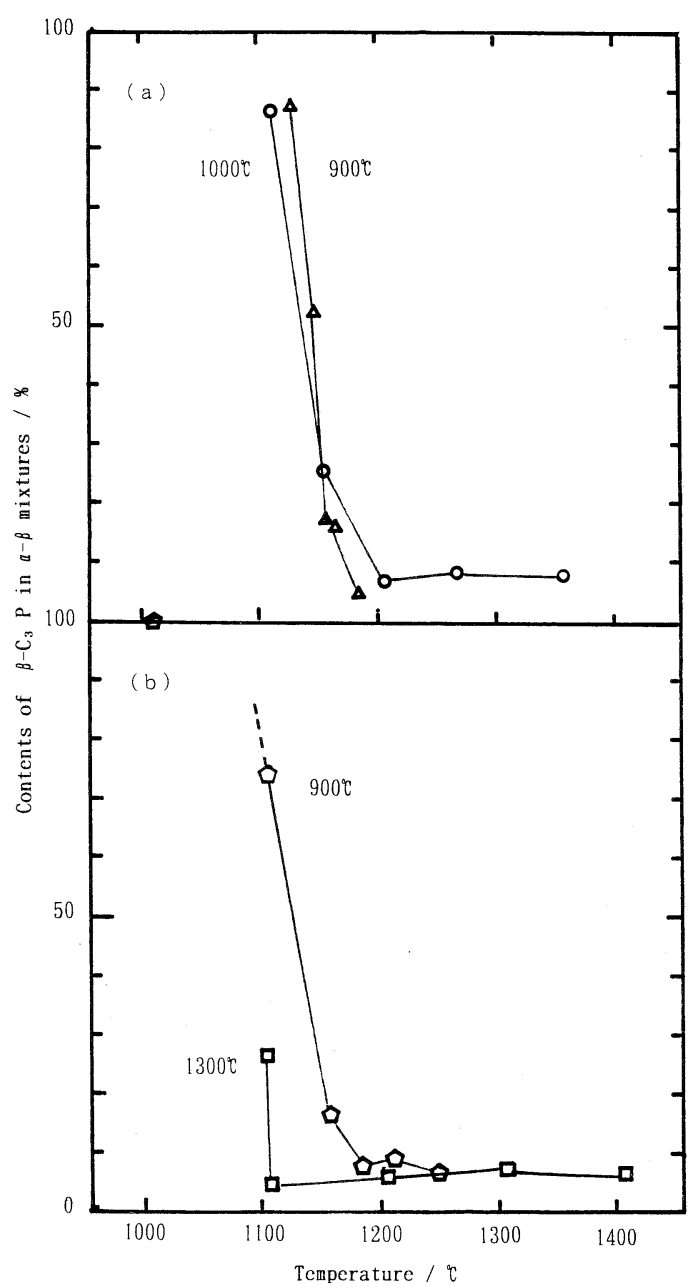

Fig. 1. Contents of $\beta-\mathrm{C}_{3} \mathrm{P}$ in mixtures with $\alpha-\mathrm{C}_{3} \mathrm{P}$ against quenched temperatures. $\alpha$ to $\beta$ transition was estimated from appearance temperature of $\alpha-\mathrm{C}_{3} \mathrm{P}$.

(a) for specimen 434 and (b) for 404, shown in Table 1. 
region in the phase diagram. To simplify, this ironfree pigeonite is abbreviated as pigeonite (pi) in this report. In the system diopside-enstatite, the pigeonite field is located only in the temperature range 1230 to $1430^{\circ} \mathrm{C}$ and at compositions $10-25$ mol\% of diopside. ${ }^{8)-11)}$ And a larger area for the presence of pigeonite was reported at $\mathrm{SiO}_{2}$-rich side in the system diopside-enstatite. In the phase diagram published in $1975,{ }^{12)}$ the lowest temperature of presence of pigeonite decreased below 1000 or even to $700^{\circ} \mathrm{C}$ from the high-temperature XRD study. In this system, forsterite is widely present up to 75 mol\% in diopside content just under the liquidus curve below which diopside solid solution, 2-phase region, above mentioned pigeonite solid solution and enstatite solid solution occupy. The diopside has no crystal transition up to its melting point, while the enstatite has 2 or 3 type of transition as below. ${ }^{12}$ )

Enstatite (Low clinoenstatite, E or LCE)

$\rightarrow$ High clinoenstatite (HCE)

$\rightarrow$ Protoenstatite (PE)

$\rightarrow$ Forsterite + liquid.

The transition temperatures are $1000-1080^{\circ} \mathrm{C}, 1230$ and $1560^{\circ} \mathrm{C}$, ${ }^{7}$ respectively. The author's publication ${ }^{7)}$ on the system $\mathrm{C}_{3} \mathrm{P}-\mathrm{MS}$ in 1958 was re-examined in this study, because the both phases of diopside and pigeonite widely formed in the system $\mathrm{C}_{3} \mathrm{P}-$ MS.

Starting materials $\mathrm{CMS}_{2}$ and MS were prepared from $\mathrm{CaCO}_{3}, \mathrm{MgO}$ and amorphous silica at $1300^{\circ} \mathrm{C}$ for $4 \mathrm{~h}$ after preliminary firings at the same temperature and regrindings. Specimen compositions were

Table 2. Quenching Experiments for the System $\mathrm{CMS}_{2}-\mathrm{MS}$. $\mathrm{d}=$ diopside $\left(\mathrm{CMS}_{2}\right)$, pi = pigeonite $\left(\mathrm{C}_{0.09} \mathrm{M}_{0.91} \mathrm{~S}\right)$, pr=protoenstatite (MS), $\mathrm{cr}=$ cristobalite and $\mathrm{f}=$ forsterite.

Order in Phases Present is According to Amounts of Them

\begin{tabular}{|c|c|c|c|c|c|c|c|c|c|}
\hline No. & $\begin{array}{c}\mathrm{CrS}_{2}-\mathrm{MS} \\
\mathrm{wt} \times \\
(\text { molx })\end{array}$ & $\begin{array}{c}\text { Hold } \\
\text { tenp. } \\
\tau\end{array}$ & $\begin{array}{l}\text { ing } \\
\text { tine } \\
h\end{array}$ & $\begin{array}{l}\text { Phases } \\
\text { present }\end{array}$ & No. & $\begin{array}{c}\mathrm{CrS}_{2}-\mathrm{YS} \\
\mathrm{tt} \times \\
(\operatorname{mol} \mathrm{x})\end{array}$ & $\begin{array}{c}\text { Hold } \\
\text { temp. } \\
r\end{array}$ & $\begin{array}{l}\text { ing } \\
\text { tine } \\
\text { h }\end{array}$ & $\begin{array}{l}\text { Phases } \\
\text { present }\end{array}$ \\
\hline 453 & $\begin{array}{c}89.6-10.4 \\
(80-20)\end{array}$ & $\begin{array}{l}1355 \\
1205 \\
1205\end{array}$ & $\begin{array}{c}1 \\
10.5 \\
8\end{array}$ & $\begin{array}{l}\text { d, cr } \\
d, c r, f \\
d\end{array}$ & 422 & $\begin{array}{c}10.2-89.8 \\
(5-95)\end{array}$ & $\begin{array}{l}1355 \\
1205 \\
1105\end{array}$ & $\begin{array}{r}1 \\
8 \\
15\end{array}$ & $\begin{array}{l}\mathrm{pi} \\
\mathrm{pi} \\
\mathrm{pi}\end{array}$ \\
\hline 454 & $\begin{array}{c}80-20 \\
(65-35)\end{array}$ & $\begin{array}{l}1105 \\
1355 \\
1205 \\
1105\end{array}$ & $\begin{array}{c}15 \\
1 \\
13.5 \\
7\end{array}$ & $\begin{array}{l}d \\
d, c r, f \\
d, c r, f \\
d\end{array}$ & 488 & $\begin{array}{l}8.2-91.8 \\
(4-96)\end{array}$ & $\begin{array}{l}1405 \\
1305 \\
1205 \\
1105\end{array}$ & $\begin{array}{l}1.5 \\
1.5 \\
5 \\
22\end{array}$ & $\begin{array}{l}\text { pi,pr } \\
\text { pi,cr } \\
\text { pi,pr,cr } \\
\text { pi,cr }\end{array}$ \\
\hline 417 & $\begin{array}{c}68.3-31.7 \\
(50-50)\end{array}$ & $\begin{array}{l}1355 \\
1205 \\
1105\end{array}$ & $\begin{array}{r}1 \\
8 \\
15\end{array}$ & $\begin{array}{l}\text { d } \\
\text { d, pi } \\
\text { d, pi }\end{array}$ & 489 & $\begin{array}{l}6.3-93.7 \\
(3-97)\end{array}$ & $\begin{array}{l}1405 \\
1305 \\
1205\end{array}$ & $\begin{array}{l}2 \\
1.7 \\
3.5\end{array}$ & $\begin{array}{l}\text { pi,pr, cr } \\
\text { pi,cr } \\
\text { pi,cr }\end{array}$ \\
\hline 418 & $\begin{array}{c}59-41 \\
(40-60)\end{array}$ & $\begin{array}{l}1355 \\
1205 \\
1105\end{array}$ & $\begin{array}{r}1 \\
18 \\
16\end{array}$ & $\begin{array}{l}\text { d, pi } \\
\text { d, pi } \\
\text { d }\end{array}$ & 486 & $\begin{array}{l}4.2-95.8 \\
(2-98)\end{array}$ & $\begin{array}{l}1105 \\
1405 \\
1355\end{array}$ & $\begin{array}{r}23 \\
1 \\
1\end{array}$ & $\begin{array}{l}\text { pi } \\
\text { pi,pr,cr,f } \\
\text { pi,pr,cr,f }\end{array}$ \\
\hline 419 & $\begin{array}{c}48-52 \\
(30-70)\end{array}$ & $\begin{array}{l}1355 \\
1205 \\
1105\end{array}$ & $\begin{array}{c}1 \\
8.5 \\
15\end{array}$ & $\begin{array}{l}p i, d \\
p i, d \\
p i, d\end{array}$ & & & $\begin{array}{l}1205 \\
1205 \\
1155\end{array}$ & $\begin{array}{r}3 \\
4 \\
52\end{array}$ & $\begin{array}{l}\text { pi,pr, cr,f } \\
\text { pi,pr,cr } \\
\text { pi,pr,cr,f }\end{array}$ \\
\hline 420 & $\begin{array}{c}35-65 \\
(20-80)\end{array}$ & $\begin{array}{l}1355 \\
1205 \\
1105\end{array}$ & $\begin{array}{r}1 \\
9 \\
17\end{array}$ & $\begin{array}{l}p i, d \\
p i, d \\
p i, d\end{array}$ & 487 & $\begin{array}{l}2.1-97.9 \\
(1-99)\end{array}$ & $\begin{array}{l}1405 \\
1305 \\
1205\end{array}$ & $\begin{array}{l}3.5 \\
1 \\
2.5\end{array}$ & $\begin{array}{l}\text { pi.pr, cr, f } \\
\text { pi,pr,cr, f } \\
\text { pi, pr, cr, f }\end{array}$ \\
\hline 421 & $\begin{array}{c}19.3-80.7 \\
(10-90)\end{array}$ & $\begin{array}{l}1355 \\
1205 \\
1105\end{array}$ & $\begin{array}{c}1 \\
8 \\
21.5\end{array}$ & $\begin{array}{l}\text { pi,cr } \\
\text { pi } \\
\text { pi }\end{array}$ & 550 & $0-100$ & $\begin{array}{l}1105 \\
1585 \\
1555 \\
1505 \\
1455\end{array}$ & $\begin{array}{l}40 \\
0.33 \mathrm{~L} \\
0.5 \\
0.66 \mathrm{p} \\
1\end{array}$ & $\begin{array}{l}\text { pi, pr,cr,f } \\
\text { pi,pr,f,cr, } L \\
p r, p i, f, c r \\
\text { pr,f,cr }\end{array}$ \\
\hline
\end{tabular}

from $80-20$ to $1-99 \mathrm{~mol} \%$ for $\mathrm{CMS}_{2}-\mathrm{MS}$ and were quenched using the same technique in the temperature range 1100 to $1400^{\circ} \mathrm{C}$. Holding time was $1-2 \mathrm{~h}$ at $1350-1400^{\circ} \mathrm{C}, 8-12 \mathrm{~h}$ at $1200^{\circ} \mathrm{C}$ and $7-50 \mathrm{~h}$ at $1100^{\circ} \mathrm{C}$. For the X-ray examinations, JCPDS data ${ }^{20)}$ were referred. Especially, data from 11-654 for diopside and 11-273 for protoenstatite were used. The X-ray data for iron-free pigeonite was cited from the literature. ${ }^{9)}$ Compositions of the mixture, temperatures and holding time in the heat treatments, and phases present examined by XRD are listed in Table 2.

Figure 2(a) shows the results of the phases present. This result in the temperature range 1105 to $1405^{\circ} \mathrm{C}$ agrees well with the results of Kushiro ${ }^{10}$ ) by quenching method rather than those of Schwab and Schwerin ${ }^{12)}$ by XRD at high-temperature. This is natural because this study used the quenching method. In the wide intermediate region, a mixture of diopside and pigeonite appeared (Fig. 2(b)). Decrease in the X-ray peak intensity for diopside begins from $50 \mathrm{~mol} \%$ of $\mathrm{MgSiO}_{3}$ with increases of pigeonite, and diopside peaks disappear at 90-95 mol\% of $\mathrm{MgSiO}_{3}$. Protoenstatite appears as a mixture with pigeonite in the region over $95 \mathrm{~mol} \%$ of $\mathrm{MgSiO}_{3}$ (Fig. 2(c)) and no clinoenstatite appeared between 1105 and $1405^{\circ} \mathrm{C}$. Formation of the diopside solid solution at the diopside side and the pigeonite solid solution were confirmed by the smooth change of $d$-value for (220) at $27.6-28.0^{\circ},(310)$ at $30.3-$ $31.0^{\circ}$ and $(002)$ at $35.5-36.3^{\circ}$ of $2 \theta$. These $d$-values slightly decrease with increasing $\mathrm{mol} \%$ of $\mathrm{MgSiO}_{3}$ (Fig. 2(d)). These changes are not understood in the present step. These results near the MS side are not perfectly consistent with those by Kushiro, ${ }^{10)}$ because pure pr solid solution phase does not appear. The results for $d$-spacing in Fig. 2(d) were employed to decide phase compositions in the system $\mathrm{CMS}_{2}-\mathrm{MS}$ as described later.

\subsection{The system $\mathrm{C}_{3} \mathrm{P}-\mathrm{MS}$}

A phase diagram on this system has been already reported in 1958 by the author. ${ }^{7)}$ As mentioned above, diopside and iron-free pigeonite were found widely in this re-examination. Thus, the diagram should be corrected to a new one. Quenching results are shown in Table 3 . The phase diagram obtained is shown in Fig. 3. Primary crystals are $\mathrm{C}_{3} \mathrm{P}(\alpha$ or $\beta)$ in a $\mathrm{C}_{3} \mathrm{P}$ side, pigeonite (pi) and forsterite ( $\mathrm{f}$ ) in an MS-side, and diopside (d) at the lowest fusion temperature region $\left(1265-1305^{\circ} \mathrm{C}\right)$ of a narrow center part. Under the solidus line, pi coexists with protoenstatite (pr) in a wide region of the MS-side. In this MS-side, $\beta$ - $\mathrm{C}_{3} \mathrm{P}$ solid appears only below $1245^{\circ} \mathrm{C}$ as mixtures with diopside, pigeonite and protoenstatite in composition above 20\% MS and clinoenstatite was not found in the temperature range 1105 to $1405^{\circ} \mathrm{C}$.

$\mathrm{C}_{2.7} \mathrm{M}_{0.3} \mathrm{P}$ formed from $\mathrm{C}_{3} \mathrm{P}$ by dissolving $\mathrm{MgO}$ from $\mathrm{MS}$ in a temperature range 1105 to $1405^{\circ} \mathrm{C}$. 

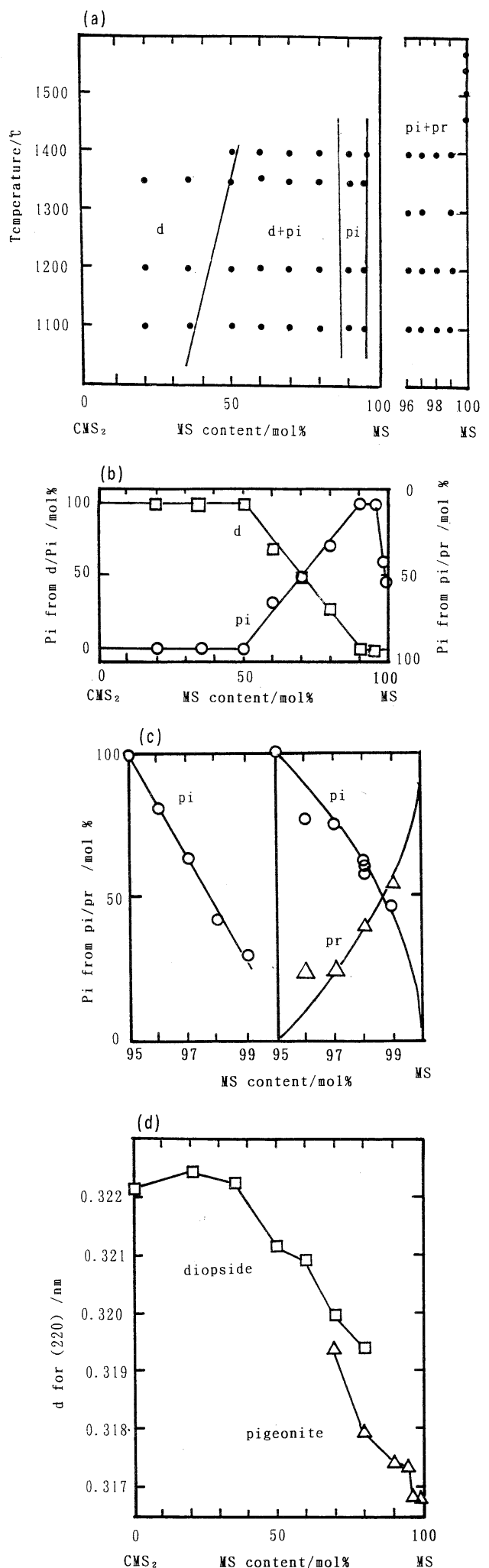

Fig. 2. (a) Phase distribution obtained from quenching results in the system $\mathrm{CMS}_{2}-\mathrm{MS}$.

(b) amounts of d and pi in the system $\mathrm{CMS}_{2}-\mathrm{MS}$ at $1355^{\circ} \mathrm{C}$. Relative amounts were obtained from peak intensity ratios $\mathrm{d}_{(002)} /$ $\mathrm{pi}_{(002)}$.

(c) amounts of pi and pr in an MS-rich region more than 95 mol\% of MS. The amounts were obtained from peak intensity ratios (left) $\mathrm{pi}_{(002)} / \mathrm{pr}_{(221)}$ and (right) $\mathrm{pi}_{(021)} / \mathrm{pr}_{(211)}$ in a temperature range $1105-1400^{\circ} \mathrm{C}$.

(d) change in $d$-spacings for $d$ and pi with compositions in the system $\mathrm{CMS}_{2}-\mathrm{MS}$, obtained from mean values at $1105-1355^{\circ} \mathrm{C}$.
Table 3. Quenching Experiments for the System $\mathrm{C}_{3} \mathrm{P}-\mathrm{MS}$ $\alpha=\alpha-\mathrm{C}_{3} \mathrm{P}, \beta=\beta-\mathrm{C}_{3} \mathrm{P}, \mathrm{d}=$ diopside $\left(\mathrm{CMS}_{2}\right), \mathrm{pi}=$ pigeonite $\left(\mathrm{C}_{0.09}\right.$ $\left.\mathrm{M}_{0.91} \mathrm{~S}\right), \mathrm{pr}=$ protoenstatite $(\mathrm{MS}), \mathrm{cr}=$ cristobalite, $\mathrm{tr}=$ tridymite, $\mathrm{f}=$ forsterite, $\mathrm{L}=$ liquid. Order in Phases Present is According to Amounts of Them

\begin{tabular}{|c|c|c|c|c|c|c|c|}
\hline \multirow{2}{*}{$\begin{array}{rl}\text { No. } C_{3} & P-\text { YS } \\
\text { It } x \\
(\text { nol x }\end{array}$} & \multicolumn{2}{|c|}{$\begin{array}{l}\text { Holding } F \\
\text { temp. time }\end{array}$} & \multirow{2}{*}{$\begin{array}{l}\text { Phases } \\
\text { present }\end{array}$} & $\begin{array}{c}\text { No. } \mathrm{C}_{3} \text { P-IS } \\
\text { wt. } \mathrm{x}\end{array}$ & $\begin{array}{l}\text { Holdi } \\
\text { temp. } t\end{array}$ & & $\begin{array}{l}\text { hases } \\
\text { present }\end{array}$ \\
\hline & & h & & $($ nol x $)$ & $r$ & h & \\
\hline $49098.3-1.7$ & 1555 & 0.66 & $a, \mathrm{~L}$ & $47645-55$ & 1325 & 1 & L \\
\hline & 1505 & 0.33 & $a, \mathrm{~d}, \mathrm{~L}$ & & 1295 & 1 & L \\
\hline$(95-5)$ & 1405 & 1 & $a, \beta, d$ & $(20.9-79.1)$ & 1285 & 3 & $\mathrm{~L}$ \\
\hline & 1305 & 1 & $\beta, a d$ & & 1275 & 1 & d, L \\
\hline & 1205 & 3 & B,d & & 1255 & 1 & d, L \\
\hline & 1105 & 14 & $\beta, d$ & & 1245 & 1 & d \\
\hline $49196.5-3.5$ & 1555 & 0.66 & $a, d, L$ & & 1225 & 2 & $\beta, \mathbf{p i}$ \\
\hline & 1505 & 0.66 & $a, d, L$ & & 1205 & 2 & $\beta, p i, p r$ \\
\hline$(90-10)$ & 1405 & 1 & $a, B, d, L$ & & 11751 & 17 & $\beta, p i, d$ \\
\hline & 1305 & 1 & $\beta, \mathbf{d}$ & $496 \quad 42.5-57.5$ & 51305 & 2 & $\mathrm{~L}$ \\
\hline & 1205 & 2.5 & $\beta, d$ & & 1295 & 2 & d, pi, L \\
\hline & 1105 & 12.5 & $B, d$ & $(19.3-80.7)$ & 1275 & 2 & d, pi, L \\
\hline $49294.6-5.4$ & 1555 & 0.66 & $a, \mathrm{~L}$ & & 1255 & 2 & B, d, pr, L \\
\hline & 1505 & 0.83 & $a, d, L$ & & 12551 & 16 & pi, $\beta, d, L$ \\
\hline (85-15) & 1405 & 2 & $\beta, a, d, L$ & & 1245 & 3 & $\beta, d$ \\
\hline & 1305 & 1 & B, d & & 1235 & 3 & $\beta, d, p i$ \\
\hline & 1205 & 3 & $\beta, d$ & & 11752 & 24 & $\beta, d, p i$ \\
\hline & 1105 & 9 & $B, d$ & $46840-60$ & 1315 & 2 & L \\
\hline $49392.5-7.5$ & 1600 & 0.5 & $a, \beta, \mathrm{L}$ & & 1305 & 1.2 & pi, L \\
\hline & 1555 & 0.66 & $a, \mathrm{~L}$ & $(17.5-82.5)$ & 1295 & 1 & pi, d, L \\
\hline$(80-20)$ & 1505 & 0.83 & $a, d, L$ & & 1275 & 1 & d, pi, L \\
\hline & 1405 & 1 & $\beta, d, L$ & & 1245 & 1 & d, pi \\
\hline & 1305 & 1 & $\beta, d$ & & 1205 & 2.5 & $\beta, p i$ \\
\hline & 1205 & 3 & $\beta, d$ & & 11551 & 15 & B, pi \\
\hline & 1105 & 15 & $\beta, d$ & & 11051 & 15 & pi, $\beta$ \\
\hline $49487.8-12.2$ & 21550 & 0.5 & $a, \mathrm{~L}$ & $45535.3-64.7$ & 71345 & 1 & L \\
\hline & 1505 & 0.83 & $a, \mathrm{~L}$ & & 1335 & 1 & pi, pr, L \\
\hline$(70-30)$ & 1405 & 1 & $B, L$ & (15-85) & 1325 & 1 & pi, pr, L \\
\hline & 1305 & 1 & $\beta, L$ & & 1295 & 1 & pi, pr, L \\
\hline & 1205 & 3 & $\beta, d$ & & 1275 & 3 & pi, pr, L \\
\hline & 1105 & 16 & $\beta, d$ & & 1255 & 1 & pi, d, L \\
\hline $48380-20$ & 1465 & 0.83 & L & & 1235 & 1 & pi, $\beta, c r$ \\
\hline & 1425 & 0.5 & $\beta, d, L$ & & 1205 & 7.5 & pi, $\beta, c r$ \\
\hline$(56.4-43.6)$ & 1355 & 2 & B, d, L & & 12051 & 15 & pi, $\beta, c r$ \\
\hline & 1305 & 1 & B, d, L & & 11552 & 21 & pi, $\beta$, pr \\
\hline & 1295 & 2 & $\beta, d, L$ & $45625.6-74.4$ & 41405 & 1 & L \\
\hline & 1295 & 2 & $\beta, d, L$ & & 1385 & 1 & pi. L \\
\hline & 1245 & 2 & $B, \mathrm{~d}, \mathrm{~L}$ & $(10-90)$ & 1355 & 1 & pi, pr, L \\
\hline & 1205 & 2.5 & $\beta$ & & 1305 & 1 & pi, pr, L \\
\hline & 1155 & 8 & $\beta, d$ & & 1265 & 1 & pi, pr, cr, \\
\hline $48270-30$ & 1365 & 1.2 & L & & 1265 & 1 & pi, pr, cr, 1 \\
\hline & 1325 & 1.5 & $\beta, \mathrm{L}$ & & 1245 & 2 & pi, pr,d \\
\hline$(43-57)$ & 1305 & 0.8 & B.L & & 1225 & 4 & pi, $\beta$, pr, Cr \\
\hline & 1285 & 1 & $\beta, d, L$ & & 12052 & 21 & pi, $\beta, p r$ \\
\hline & 1245 & 2 & B, d, L & & 11554 & 45 & cr, pi, B, pr \\
\hline & 1205 & 13 & $\beta, d$, & $45714-86$ & 1450 & 1 & $\mathbf{L}$ \\
\hline & 1155 & 8 & $B, d$ & & 1425 & 0.6 & pi, L \\
\hline & 1155 & 15 & $\beta, d$ & (5-95) & 1405 & 1 & pi, pr, L \\
\hline $47860-40$ & 1325 & 1 & L & & 1355 & 1 & pi, pr, L \\
\hline & 1315 & 1 & $\mathrm{~L}$ & & 1305 & 1 & pi, pr, L \\
\hline$(32.7-67.3)$ & 1295 & 1 & $\beta, L$ & & 1265 & 2 & pi, pr, cr \\
\hline & 1295 & 1 & $\beta, \mathrm{L}$ & & 1255 & 1 & pi, pr, cr \\
\hline & 1265 & 1 & $\beta, d, L$ & & 12451 & 15 & pi, pr, cr \\
\hline & 1205 & 2 & B,d & & 1225 & 4 & pi, $\beta, p r, c r$ \\
\hline & 1185 & 15 & $\beta, d$ & & 12051 & 19 & pi, pr, $\beta$ \\
\hline & 1155 & 15 & $\beta, d, p i$ & & 11555 & 54 & pi,, , pr \\
\hline $49555-45$ & 1305 & 1.5 & L & $467 \quad 6-94$ & 1500 & 1 & pi, pr, L \\
\hline & 1280 & 2 & $\beta, d, L$ & & 1405 & 1 & pi, pr \\
\hline$(28.3-71.7)$ & 1265 & 2.5 & d, $\beta$ & $(2-98)$ & 1355 & 1.5 & pi, pr, cr \\
\hline & 1245 & 3 & $\beta, d$ & & 1275 & 1.5 & pi, pr, L \\
\hline & 1235 & 6 & $\beta, d$ & & 1245 & 2 & pi, pr, cr \\
\hline & 1215 & 41 & B, d & & 1205 & 2 & pi, pr \\
\hline & 11952 & 23 & $\beta, d$ & & 1155 & 3 & pi, pr \\
\hline $56252-48$ & 1255 & 1.5 & d, $\beta, L$ & & 11051 & 15 & pi, pr \\
\hline & 1235 & 1.5 & $\beta, d$ & $4812-98$ & 1575 & 0.33 & $\mathrm{~L}$ \\
\hline$(26-74)$ & 1225 & 1.5 & $\beta, d$ & & 1555 & 0.83 & pi, pr, L \\
\hline $47750-50$ & 1285 & 1 & L & $(0.7-99.3)$ & 1405 & 1 & pi, pr, cr \\
\hline & 1275 & 1 & $\mathbf{L}$ & & 1305 & 2 & pi, pr, cr \\
\hline$(24.5-75.5)$ & 1265 & 1 & d, $\beta, L$ & & 1205 & 1.2 & pr, pi \\
\hline & 1255 & 2 & $d, \beta, L$ & & 1205 & 2 & pi, pr \\
\hline & 1245 & 1 & d, $\beta$ & & 1155 & 3 & pi, pr, cr \\
\hline & 1155 & 16 & $\beta, d, p i$ & & 11051 & 15 & pi, pr, cr \\
\hline $485 \quad 47.5-52.5$ & 51275 & 1 & $\mathrm{~L}$ & $484 \quad 1-99$ & 1575 & 0.33 & $\mathrm{~L}$ \\
\hline & 1265 & 1 & d, L & & 1555 & 0.33 & pi, pr, L \\
\hline$(22.6-77.4)$ & ) 1255 & 1 & d, L & $(0.3-99.7)$ & ) 1505 & 0.33 & pi, pr, L \\
\hline & 1245 & 1 & $B, d, L$ & & 1455 & 1 & pr, f, cr \\
\hline & 1245 & 1.5 & d & & 1305 & 1 & pi, pr, cr \\
\hline & 1235 & 1.5 & $\beta, d$ & & 1205 & 4 & pi, pr, cr \\
\hline & 1235 & 1 & $\beta, d, p i$ & & 11051 & 15 & pi, pr, cr \\
\hline & 1205 & 1 & $\beta, d, p i$ & $0-100$ & 1585 & 0.33 & L \\
\hline & & & & & 1555 & 0.5 & pi, pr, f \\
\hline & & & & & 1505 & 0.66 & pr, pi, f \\
\hline & & & & & 1455 & 1 & pr, f, cr \\
\hline
\end{tabular}




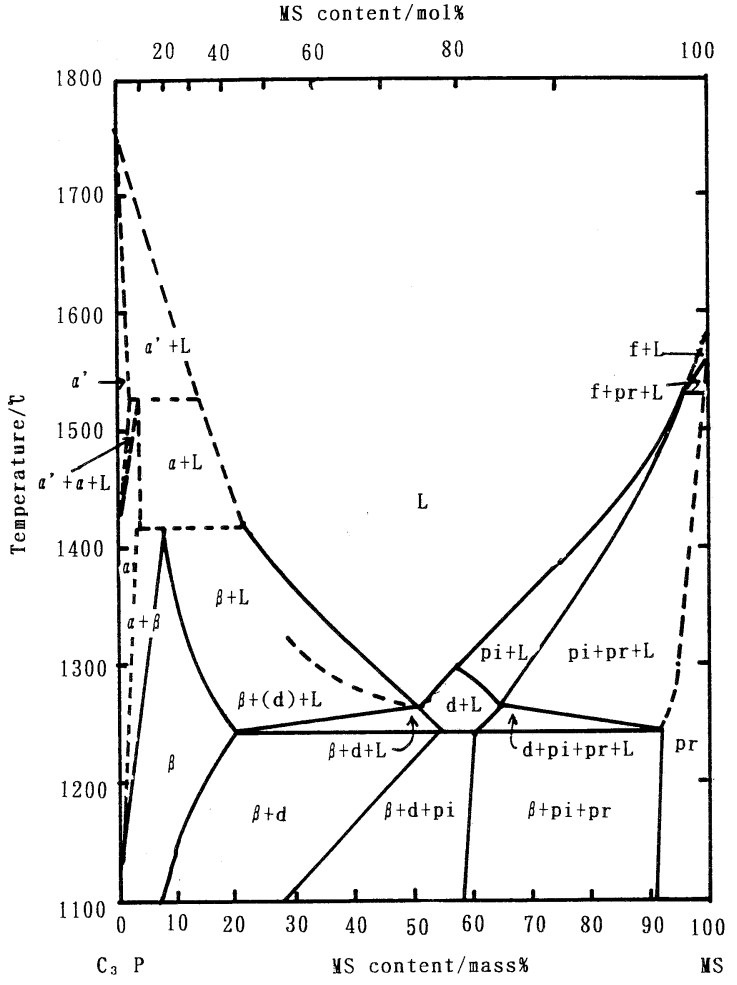

Fig. 3. Phase diagram in the system $\mathrm{C}_{3} \mathrm{P}-\mathrm{MS}$. All the dotted lines are those estimated.

This phosphate is whitrockite with same type as pure $\beta-\mathrm{C}_{3} \mathrm{P}$. From peak intensity ratios of $(034)$ at $30.7^{\circ}$ of $2 \theta$ for $\alpha-\mathrm{C}_{3} \mathrm{P}$ against $(0210)$ at $31.1^{\circ}$ of $2 \theta$ for $\beta-\mathrm{C}_{3} \mathrm{P}$, contents of both types were roughly determined as shown in Fig. 4(a). Alpha- $\mathrm{C}_{3} \mathrm{P}$ disappears above $8 \mathrm{~mol} \%$ of $\mathrm{MS}$ at $1300^{\circ} \mathrm{C}$ and above $17 \mathrm{~mol} \%$ at $1400^{\circ} \mathrm{C}$. All the $d$-values for $\beta$ - $\mathrm{C}_{3} \mathrm{P}$ decrease with
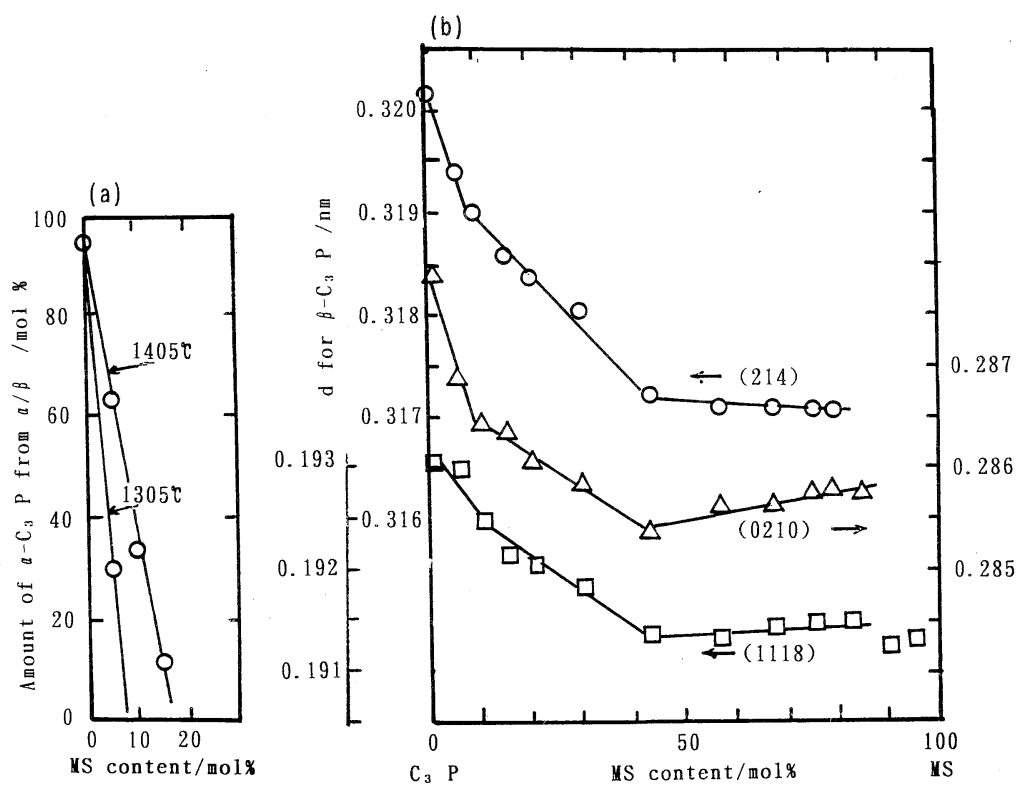

Fig. 4. (a) Amount of $\alpha-\mathrm{C}_{3} \mathrm{P}$ at 1305 and $1405^{\circ} \mathrm{C}$ in the $\mathrm{C}_{3} \mathrm{P}$ side.

(b) change in mean $d$-values for $\beta$ - $\mathrm{C}_{3} \mathrm{P}$ widely formed in the system $\mathrm{C}_{3} \mathrm{P}-\mathrm{MS}$ in the temperature range $1155-1425^{\circ} \mathrm{C}$.

(c) - (e) change in mean $d$-values for $\mathrm{d}$, pi and pr in the MS side of the system $\mathrm{C}_{3} \mathrm{P}-\mathrm{MS}$ in the temperature range $1155-1425^{\circ} \mathrm{C}$. additions of MS to $42 \mathrm{~mol} \%$ (20 mass\%) accompanying a small break at $10-15 \mathrm{~mol} \%$ till which $\alpha$ $\mathrm{C}_{3} \mathrm{P}$ coexists with $\beta$ - $\mathrm{C}_{3} \mathrm{P}$. And then smaller variation (increase or decrease) is seen up to about $90 \mathrm{~mol} \%$ of MS, as shown in Fig. 4(b). The decrease in $d$ value for $\beta-\mathrm{C}_{3} \mathrm{P}$ up to $42 \mathrm{~mol} \%$ is due to the formation of solid solution with increasing $\mathrm{MgO}$. These decreases occur by substitution of $\mathrm{Mg}$-ion to $\mathrm{Ca}$-ion site in $\beta-\mathrm{C}_{3} \mathrm{P}$. Smaller variations up to about 85 mol\% MS are seen in the composition range of coexistence with pigeonite.

A reason of the coexistence of diopside in the system $\mathrm{C}_{3} \mathrm{P}-\mathrm{MS}$ is discussed here. As mentioned above, $\beta-\mathrm{C}_{3} \mathrm{P}$ dissolves $\mathrm{MgO}$ component of about $10-15$ mol\% in maximum to form whitrockite. Thus it is thought that removed $\mathrm{CaO}$ reacts with $\mathrm{MS}$ component to form diopside. Assuming maximum solubilities of 10,15 and $20 \mathrm{~mol} \%$ of $\mathrm{MgO}$ against $\mathrm{CaO}$ in $\mathrm{C}_{3} \mathrm{P}$ ( $x$ in $\mathrm{C}_{3-x} \mathrm{M}_{x} \mathrm{P}=0.3,0.45$ and 0.6 , respectively), moles of formed $\mathrm{CMS}_{2}$ and solid solution of $\mathrm{CMS}_{2}-$ MS were calculated as listed in Table 4.

In $\mathrm{C}_{3} \mathrm{P}-\mathrm{MS}$ compositions of $9-1,8-2$ and $7-3 \mathrm{~mol}$, $\mathrm{C}_{3-x} \mathrm{M}_{x} \mathrm{P}(x=0-0.3)$ first forms by dissolving $\mathrm{MgO}$ from $\mathrm{MS}$, and then liberated $\mathrm{CaO}$ reacted with $\mathrm{MS}$ to form diopside. In 6-4-3-7 compositions, saturated whitrockite $\mathrm{C}_{2.7} \mathrm{M}_{0.3} \mathrm{P}$ first forms and then phases in the system $\mathrm{CMS}_{2}-\mathrm{MS}$ forms. In 2-8-0.2-9.8 compositions pigeonite forms with saturated whitrockite. These above calculations for $x=0.3$ agree well with

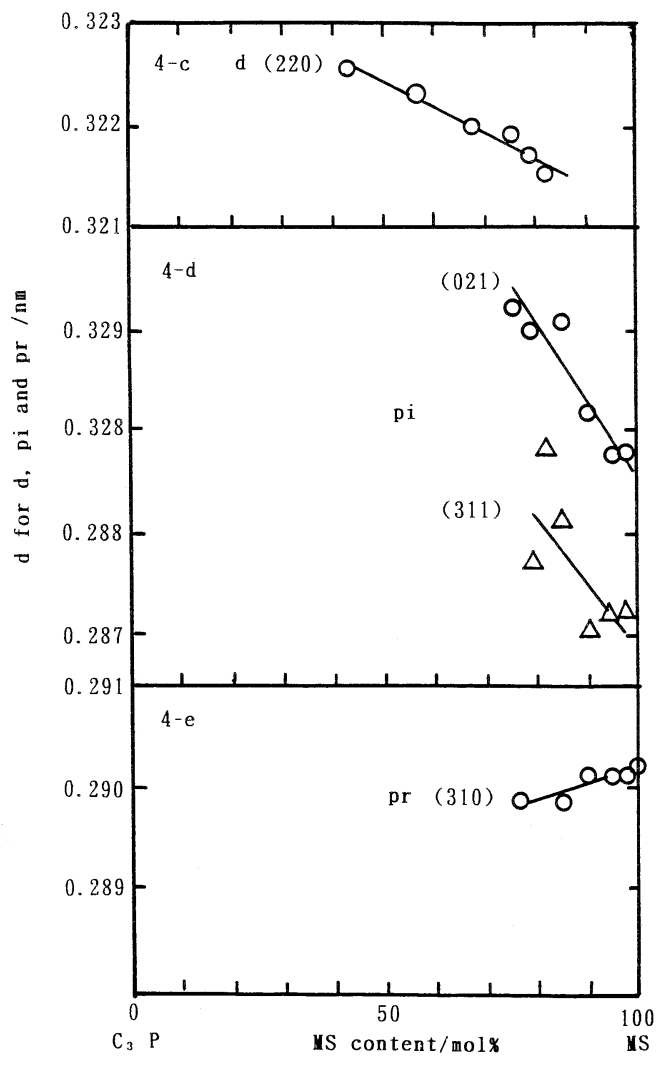


Table 4. Calculations for Formations of Mg-Containing Tricalcium Phosphate $\mathrm{Ca}_{3-\mathrm{x}} \mathrm{Mg}_{\mathrm{x}}\left(\mathrm{PO}_{4}\right)_{2}=\mathrm{C}_{3-\mathrm{z}} \mathrm{M}_{\mathrm{x}} \mathrm{P}$ and Diopside-Enstatite (d-e, mol \%) Solid Solution.

(A) Constant $d$-Spacing for $\mathrm{CMS}_{2}$, (B) Formation of d-e Solid Solution, (C) Pigeonite Formation

\begin{tabular}{|c|c|c|c|c|c|c|c|}
\hline $\mathrm{C}_{3} \mathrm{P}-\mathrm{MS}$ & & Compo & sition of solid & soluti & ons & & \\
\hline & $x=0.3$ & & $x=0.45$ & & $x=0.6$ & & \\
\hline $9-1$ & $\begin{array}{l}\mathrm{C}_{2.94} 0.0{ }_{06} \mathrm{P} \\
\mathrm{d}\end{array}$ & $\begin{array}{l}9 \\
0.5\end{array}$ & same as the & eft & same as the le & & \\
\hline $8-2$ & $\begin{array}{l}C_{2.87}{ }_{0.13} P \\
d\end{array}$ & $\begin{array}{l}8 \\
1\end{array}$ & same as the & eft $t$ & same as the $1 \mathrm{e}$ & & \\
\hline $7-3$ & $\begin{array}{l}C_{2.79} \quad 0 .{ }_{21} \mathrm{P} \\
\text { d }\end{array}$ & $\begin{array}{l}7 \\
1.5\end{array}$ & same as the & eft & same as the le & & (A) \\
\hline $6-4$ & $\begin{array}{l}\mathrm{C}_{2.7} \mathrm{H}_{0.3} \mathrm{P} \\
\mathrm{d}-\mathrm{e}(82-18) \\
\text { or d }\end{array}$ & $\begin{array}{l}6 \\
2.2 \\
2.0\end{array}$ & 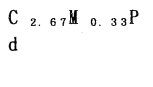 & $\begin{array}{l}6 \\
2\end{array}$ & same as the $1 \mathrm{e}$ & & \\
\hline $5-5$ & $\begin{array}{l}C_{2.7} \text { H }_{0.3} P \\
\text { d-e }(43-57)\end{array}$ & $\begin{array}{l}5 \\
3.5\end{array}$ & $\begin{array}{l}C_{2 .}{ }_{55}{ }_{0 .}{ }_{45} P \\
\text { d-e }(82-18)\end{array}$ & $\begin{array}{l}5 \\
2.75\end{array}$ & $\begin{array}{l}C_{2.5} \\
\text { d }\end{array}$ & $\begin{array}{l}5 \\
2.5\end{array}$ & \\
\hline $4-6$ & $\begin{array}{l}\mathrm{C}_{2.7} \mathrm{~W}_{0.3} \mathrm{P} \\
\mathrm{d}-\mathrm{e}(25-75)\end{array}$ & $\begin{array}{l}4 \\
4.8\end{array}$ & $\begin{array}{l}C_{2} 2.55{ }_{0.45} P \\
d-e(43-57)\end{array}$ & $\begin{array}{l}4 \\
4.2\end{array}$ & $\begin{array}{l}\mathrm{C}_{2.4} \mathbf{Y}_{0.6} \\
\mathrm{~d}-\mathrm{e}(67-33)\end{array}$ & $\begin{array}{l}4 \\
3.6\end{array}$ & \\
\hline $3-7$ & $\begin{array}{l}\mathrm{C}_{2.7} \mathrm{H}_{0.33} \mathrm{P} \\
\mathrm{d}-\mathrm{e}(15-81)\end{array}$ & $\begin{array}{l}3 \\
6.1\end{array}$ & $\begin{array}{l}C_{2.55}{ }_{2 .}{ }_{45} \mathrm{P} \\
\mathrm{d}-\mathrm{e}(24-76)\end{array}$ & $\begin{array}{l}3 \\
5 .\end{array}$ & $\begin{array}{l}C_{2.4} \text { H }_{0.6} \\
\text { d-e }(35-65)\end{array}$ & $\begin{array}{l}3 \\
5.2\end{array}$ & (B) \\
\hline $2-8$ & $\begin{array}{l}C_{2,7} \text { o. }_{3} P \\
\text { d-e }(8-92)\end{array}$ & $\begin{array}{l}2 \\
7.4\end{array}$ & 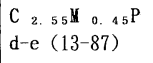 & $\begin{array}{l}2 \\
7.1\end{array}$ & $\begin{array}{l}C_{2.4} \text { M }_{0.6} \\
\text { d-e }(18-82)\end{array}$ & $\begin{array}{l}2 \\
6.8\end{array}$ & \\
\hline $1-9$ & $\begin{array}{l}\mathrm{C}_{2.7} \text { o.3 }_{\mathrm{P}} \\
\mathrm{d}-\mathrm{e}(3.6-96.4)\end{array}$ & $\begin{array}{l}1 \\
8.7\end{array}$ & $\begin{array}{l}\text { C } 2.55 \text {. } 0.45 \\
\text { d-e }(5.3-94.7)\end{array}$ & $\begin{array}{l}1 \\
8.6\end{array}$ & $\begin{array}{l}C_{2.4} y_{0.6} P \\
\text { d-e }(7-93)\end{array}$ & $\begin{array}{l}1 \\
8.4\end{array}$ & \\
\hline $0.5-9.5$ & $\begin{array}{l}\mathrm{C}_{2.7} \text {. }_{0.3} \mathrm{P} \\
\mathrm{d}-\mathrm{e}(1.6-98.4)\end{array}$ & $\begin{array}{l}0.5 \\
9.35\end{array}$ & $\begin{array}{l}\mathrm{C}_{2 .}{ }_{55} \mathrm{II}_{0.45} \mathrm{P} \\
\mathrm{d}-\mathrm{P}(2.4-97.6)\end{array}$ & $\begin{array}{l}0.5 \\
9.27\end{array}$ & $\begin{array}{l}C_{2.4} \text { O. }_{0.6} \\
\text { d-e }(3.3-96.7)\end{array}$ & $\begin{array}{l}0.25 \\
9.2\end{array}$ & (C) \\
\hline $0.2-9.8$ & $\begin{array}{l}\mathrm{C}_{2.7} \mathrm{Y}_{0.3} \mathrm{P} \\
\mathrm{d}-\mathrm{e}(0.8-99.2)\end{array}$ & $\begin{array}{l}0.25 \\
9.68\end{array}$ & $\begin{array}{l}C_{2.55}{ }_{2 .}{ }_{0.45} \mathrm{P} \\
\text { d-e }(1.2-98.8)\end{array}$ & $\begin{array}{l}0.25 \\
9.64\end{array}$ & $\begin{array}{l}\mathrm{C}_{2.4} \mathrm{H}_{0.6} \mathrm{P} \\
\mathrm{d}-\mathrm{e}(1.6-98.4)\end{array}$ & $\begin{array}{l}0.25 \\
9.60\end{array}$ & \\
\hline
\end{tabular}

the results of the phase diagram as shown in Fig. 3. The calculations as $x=0.45$ and 0.6 did not agree to the experimental results.

The decrease in $d$-spacing of $\beta$ - $\mathrm{C}_{3} \mathrm{P}$ up to $40 \mathrm{~mol} \%$ MS (Fig. 4(b)) is due to a dissolution of $\mathrm{MgO}$ in $\beta$ $\mathrm{C}_{3} \mathrm{P}$ up to the $7-3$ or $6-4$ composition. Over $40 \mathrm{~mol} \%$ $\mathrm{MS}, \boldsymbol{\beta}-\mathrm{C}_{3} \mathrm{P}$ has a constant content of $\mathrm{MgO}$, and $\mathrm{CMS}_{2}$ content in the $\mathrm{CMS}_{2}-\mathrm{MS}$ solid solution decreases accompanying decrease in $d$-value (Fig. 4(c)). Above $80 \mathrm{~mol} \% \mathrm{MS}, \mathrm{CMS}_{2}$ content becomes less than 10 $\mathrm{mol} \%$ in the $\mathrm{CMS}_{2}-\mathrm{MS}$ system and pi begins to form as a major phase. The $d$-value of pi decreases with increasing MS contents and increasing $\mathrm{MgO}$ content in pi (Fig. 4(d)). The $d$-value for pr shows only a little increase to the MS-side (Fig. 4(e)).

In these results, there remains obscure facts. First is that $\alpha^{\prime}-\mathrm{C}_{3} \mathrm{P}$ phase was not determined by this quenching experiment. The highest temperature form $\alpha^{\prime}-\mathrm{C}_{3} \mathrm{P}$ had been detected only by the high-temperature XRD. ${ }^{12)}$ Accordingly the phase relation for the $\mathrm{C}_{3} \mathrm{P}$ side at the highest temperature region was only assumed. Secondly is the easy appearance of diopside (d) even up to $1420^{\circ} \mathrm{C}$, and wide coexistence with $\beta$ - $\mathrm{C}_{3} \mathrm{P}$ plus liquid. It might be due to an impossible quenching of the liquid. Thirdly is a problem in the MS side. Cristobalite appeared at 65 mass \% MS below $1235^{\circ} \mathrm{C}, 94 \%$ below $1355^{\circ} \mathrm{C}, 98 \%$ below $1405^{\circ} \mathrm{C}, 99 \%$ below $1455^{\circ} \mathrm{C}$ and $100 \%$ below $1455^{\circ} \mathrm{C}$.
Pigeonite also appeared even in the heated pure MS. These results are thought from a non-equilibrium reason for the MS-rich side. Forsterite formed by the decomposition of pure MS above $1550^{\circ} \mathrm{C}$. Whereas, in 99 mass\% MS composition and even in pure MS, pi already appears in coexistence with pr. pi appears in a wide composition range more than 40 mass $\%$ MS above $1100^{\circ} \mathrm{C}$.

\section{Conclusion}

The transition temperature from $\beta$ - to $\alpha$-type of $3 \mathrm{CaO} \cdot \mathrm{P}_{2} \mathrm{O}_{5}\left(\mathrm{C}_{3} \mathrm{P}\right)$ and phase relation in the system $\mathrm{CaO} \cdot \mathrm{MgO} \cdot 2 \mathrm{SiO}_{2}-\mathrm{MgO} \cdot \mathrm{SiO}_{2} \quad\left(\mathrm{CMS}_{2}-\mathrm{MS}\right)$ were re-examined in the temperature range 1100 to $1600^{\circ} \mathrm{C}$ and a consistence with published results was mostly confirmed. In the system $\mathrm{C}_{3} \mathrm{P}-\mathrm{MS}$, both pyroxene compounds of diopside and pigeonite widely occurred as respective solid solution. $\mathrm{C}_{3} \mathrm{P}$ takes $\beta$ type whitrockite due to dissolution of $\mathrm{MgO}$, and its transition temperature of $\beta$ to $\alpha$ rises with $\mathrm{MgO}$ contents. MS appears as pigeonite taking $\mathrm{CaO}$. Major primary crystals are $\beta-C_{3} \mathrm{P}$ in the $\mathrm{C}_{3} \mathrm{P}$ side and pigeonite in the MS-side. Minimum liquidus temperature is $1265^{\circ} \mathrm{C}$ where primary crystals are $\beta-\mathrm{C}_{3} \mathrm{P}$ and diopside, and the diopside primary crystal appears in a narrow composition range (43-49 mass\% MS). Under the liquidus curve, $\beta-\mathrm{C}_{3} \mathrm{P}$ coexist with diopside as a non-equilibrium phase in the $\mathrm{C}_{3} \mathrm{P}$-side. Above $1245^{\circ} \mathrm{C}$ where no $\beta-\mathrm{C}_{3} \mathrm{P}$ appears, diopsidepigeonite mixture and pigeonite-protoenstatite mixture exist with liquid. Below the solidus at $1245^{\circ} \mathrm{C}$, the liquid disappears and $\beta-\mathrm{C}_{3} \mathrm{P}$ remains accompanying with pigeonite and protoenstatite in a wide region up to $90 \% \mathrm{MS}$. As seen from the phase diagram, this $\mathrm{C}_{3} \mathrm{P}-\mathrm{MS}$ system is not perfect binary, having complex distribution of the phases, and accompanying both transitions of $\mathrm{C}_{3} \mathrm{P}$ and $\mathrm{MS}$ and both solid solution formations of $\mathrm{C}_{3} \mathrm{P}-\mathrm{M}$ and $\mathrm{CMS}_{2}-\mathrm{MS}$. This system should be understood from view points of the ternary system $\mathrm{C}_{3} \mathrm{P}-\mathrm{M}-\mathrm{S}$ and the quarternary system $\mathrm{C}_{3} \mathrm{P}-\mathrm{CMS}_{2}-\mathrm{MS}-\mathrm{S}$.

\section{References}

1) J. H. Welch and W. Gutt, J. Chem. Soc., 874, 4442-44 (1961).

2) G. Tromel, Stahl und Eisen, 63, 21-30 (1943).

3) G. Tromel, H. J. Harkort and W. Hotop, Z. Anorg. Chem., 256, 253-72 (1948).

4) W. L. Hill, G T. Faust and D. S. Reynolds, Am. J. Sci., 242, 470-72 (1944)

5) W. L. Hill, G. T. Faust and D. S. Reynolds, Am. J. Sci., 242, 473-77 (1944).

6) Nat. Bur. Standards, "Phase Diagrams for Ceramists", Ed. by Am. Ceram. Soc. (1964).

7) T. Sata, Bull. Chem. Soc., Japan, 31, 408-12 (1958).

8) F. R. Boyd and J. P. Schairer, J. Petrol., 5, 275-309 (1964).

9) H.-Y. Yang and W. R. Foster, Am. Mineral, 57 1232-41 (1972).

10) I. Kushiro, Am. Mineral., 57, 1260-71 (1972).

11) H.-Y. Yang, Am. J. Sci., 273, 488-97 (1973).

12) R. G. Schwab and M. Schwerin, Neues Jahrb. Mineral Abh., 124 [3] 223-45 (1975). 
13) R. Kiyoura and T. Sata, Kogyo-Kagaku-Zasshi, 54, 756-58 (1951).

14) R. Kiyoura and T. Sata, Kogyo-Kagaku-Zasshi, 56, 666-69 (1953).

15) R. Kiyoura and T. Sata, Kogyo-Kagaku-Zasshi, 56, 748-50 (1953).

16) T. Sata and R. Kiyoura, Kogyo-Kagaku-Zasshi, 62, 63-64 (1959).

17) T. Sata and R. Kiyoura, Kogyo-Kagaku-Zasshi, 62, 65-67 (1959).

18) R. Kiyoura and T. Sata, Yogyo-Kyokai-Shi, 59, 530-32 (1951).
19) R. Kiyoura and T. Sata, Yogyo-Kyokai-Shi, 62, 121-22 (1954).

20) JCPDS-International Centre for Diffraction Data, Powder Diffraction File, Set 1-36, 1974-90.

21） R. W. Nurse, J. H. Welch and W. Gutt, J. Chem. Soc., 1959, 1077-83 (1959).

22) W. Fix, H. Heymann and R. Heinke, J. Am. Ceram. Soc., 52, 346-47 (1969).

23) N. L. Bowen, Am. J. Sci., 4th Ser., 38, 207-64 (1914).

24) L. Atlas, J. Geol., 60, 140-47 (1952).

25) H. Kuno and H. H. Hess, Am. J. Sci., 251, 741-52 (1953).

26) H. H. Hess, Am. Mineral., 34, 621-66 (1949). 